\title{
Reuse Intention of Internet Primary Bank with IT Convergence: An Extended Technology Acceptance Model Study
}

\author{
Jiyoung Yoon and Soonhee Joung* \\ Department of Consumer Studies, Ewha Womans University, Republic of Korea \\ jsh@ewha.ac.kr*
}

\begin{abstract}
Due to the rapid spread of IT and services, most banking services are turning to boost a finance industry. Fintech, a combination of finance and technology, has created a new financial transaction model that is differentiated from existing financial transaction methods by combining innovative ideas and advanced technologies. The development of this innovative technology industry has especially influenced mobile technology, and furthermore, it has promoted the growth of the financial industry. In Korea, the internet primary bank was combined with new financial services with fintech IT convergence in 2017. The internet primary bank combined with these advanced technologies have made a big difference in Korea's financial market. It was also surprising to see the number of consumers in Korea. But, really important is to maintain a consistent customer reuse intention. This study investigated factors affecting the intention to continuously use it for consumers using Kakao Bank, which shows a higher status of subscription retention than K-Bank. This study aims to analyze the factors affecting the actual reuse intention through the experience of using internet primary bank. For this study, the main variables of the expanded technology acceptance model were modified and applied to establish a research model for variables affecting the intention to reuse. This research can help for marketing by checking the impact variables on the internet primary bank reuse intention. And we would like to draw implications for successful stabilization of internet primary banking in South Korea.
\end{abstract}

Keywords: Internet primary bank, financial services, fintech, IT convergence, Extended Technology Acceptance model, intention to reuse, South Korea.

\section{Introduction}

In the era of 'The Fourth Industrial Revolution', the financial industry quickly developed as a convergence industry of financial information technology 
incorporating big data technology. An innovative financial service, the internet primary bank, has emerged in a new way with a global trend (Chris, 2015). Kim \& Kim (2017) said that the core space of financial services has been expanded online due to internet primary bank (Kim \& Kim, 2017). With the global financial market trend being reorganized around IT technology and data, the so-called digital bank era has opened in Korea as internet primary bank have started in earnest (Chris, 2015).

Internet primary banks with fintech will continue to spread and are expected to (Song, 2017), which has already made a big difference in the Korean market's financial industry. As in internet primary bank has a strong advantage in improving consumer convenience and usability by IT convergence, which combines advanced information and communication technology and finance. In Korea, 'K Bank' started in April 2017, and 'Kakao Bank' opened in July of the same year. Two Internet banks launched higher rate deposits and savings products than existing banks, and offered lower loan interest and fees (Yu, 2019). These are strong advantage in improving consumer convenience and usability by IT convergence, which combines advanced information and communication technology and finance. Like this, internet primary bank had quite an unconventional customer experience. K-Bank, Korea's first internet bank, opened 20,000 accounts on its first day of business (Cha, 2018). As a latecomer, Kakao Bank actively used 'Kakao Talk', a Korean national messenger, for financial marketing, surprisingly opening 30,500 new accounts and KRW 50 billion on the first day of business. In addition, it exceeded 3.07 million subscribers in the first month of operation, earning a record of 1.40 trillion won in credit and 1.95 trillion won in reception (Cha, 2018). But, more importantly for financial industry, the part will be to keep the number of customers constantly, ie to increase the intention to reuse existing customers (Yoon \& Joung, 2019A).

According to EY(2017)'s ' Fintech Adoption Index 2017 ', Korea's adoption rate of fintech was 32\%, which was less than the average of $33 \%$ of 20 surveyed countries such as the US, Japan (EY, 2017). Moreover China is $69 \%$ of cases (EY, 2017). And even in the case of Korea's Internet primary banks, the number of consumers showed high interest in opening accounts in 2017 when they entered the market, but as of 2019 , about $80 \%$ of the account openers were reused. In other words, many people are interested in new technologies, but research on them should be followed for stable settlement (EY, 2017).

In such situation, it is important for internet primary banks to find the ways to make their existing customers reuse intention with their services and retain them. Therefore, the purposes of this study is to examine how consumers experience variables affect intention to reuse internet primary banks. And according to the results of the 'Korea Media Panel Survey in 2018' conducted by the 'Korea Information Society Development Institute (Sim, 2019)', the characteristics of internet primary bank users analyzed by 8987 people were the highest at $32.9 \%$ in 
their 20 s, and even $11.1 \%$ in their 50s the use rate of double digits was shown, but it was very low in their 60s or older (Sim, 2019). Therefore, this study investigated the factors affecting the intention of reuse of internet primary bank for consumers using Kakao Bank, which shows a higher customer retention status than K-bank (Choi \& Kim, 2017). And for this study, the variables of the extended technology acceptance model were applied through the consideration of previous studies, a research model was set up for factors affecting the intention to reuse of internet primary bank (Yoon \& Joung, 2019A). So, this study intends to conduct empirical investigations focusing on Kakao Bank with regard to the intention to use internet primary bank in Korea, which is relatively in the early stages of introduction.

Therefore, this study aims to examine the meaning of variables that influence the reuse intention of internet primary banks based on the extended technology acceptance model that can explain human acceptance of new technologies.

\section{Theoretical Backgrounds}

\subsection{Fintech and Internet primary bank}

In Korea, the introduction of specialized banks was promoted by the demand The Fintech, which has recently drawn attention, has suffered a remarkable revolution in the final sector. In other words, fintech is an industry that uses IT technology to make the financial system more efficient (McAuley, 2014). Fintech - integrated banking services have provided innovative and new financial services to customers, and new social network access can be carried out (Song, 2017). Of course, the banking service with fintech provides the same deposits, savings, and loans as existing banks. However, the key factor that is differentiated from existing banks is that all services are conducted through digital. For this reason, the resistance to consumer participation is very low, and interest in fintech technology is increasing, especially in the younger generation who have easy access to mobile technology. Jeffrey (2014) said that in a study of the US banking industry, fintech does not act as a major cause of the traditional banking market, but it shows the ability to take customers away from mainstream banks (Jeffrey, 2014). As such, the global trend of consumers not looking for branches of banks is expected to accelerate further, and this change is expected to continue with the rapid development of the web and mobile internet primary Bank.

As consumers are gradually decreasing their visits to bank branches, the emergence of Internet-based banks that combine fintech technology has made many changes in Korean society. Internet primary bank is that do not have any branch offices or have only a handful of branches and run most of the banking business through the internet, electronic media (Kang, 2017). According to the 'Korea financial supervisory service', the internet primary bank is used as a sales channel only (The Korea Financial Supervisory Service, 2016). 
In 2017, K-Bank and Kakao Bank started operations as the first internet primary bank in Korea. These banks have attracted many consumers through the advantages of easy account opening and low fees, which were difficult to experience through banks in the past. Internet primary banks offer services while offering their own advantages.

In K-Bank, which was the first internet primary bank, was also surprising to see the number of consumers. More notably, Kakao Bank, a latecomer, shown a very surprising level of high enrollment in a short period of time (Korea Economy, 2018). As you see in Table 1, according to Kakao Bank has a very simple and intuitive mobile application service, and has the advantage of using the image of a familiar character as a check card or a sticker to provide consumers with a kind of pleasure (Financial Services Commission, 2017). Also simple remittance based on the 'Kakao Talk address book', simple payment, simple screening small loans, simple overseas remittance (one-tenth of the commission and telegraphic transfer fee exemption service compared to the market bank), small business loans, Kakao Bank Friends check cards, fee exemption, etc. K-Bank did not link with specialized social services such as 'Kakao Talk', but it also promoted the strength of being Korea's first Internet primary bank and promoted the marketing of familiar images using 'Line Friends' characters. Also, it rating using bigdata, simple payment, telephone address book-based simple remittance, medium-interest personal credit loans, small credit loans for simple screening, quick remittance, K-Bank check cards, insurance Business, temporal feedback, etc. The present invention provides a device for manufacturing a device (Financial Services Commission, 2017).

Table 1: Two internet primary bank in Korea

\begin{tabular}{|c|c|c|}
\hline & Kakao Bank & K-Bank \\
\hline $\begin{array}{l}\text { Business } \\
\text { Initiation }\end{array}$ & 2017.7 & 2017.4 \\
\hline $\begin{array}{l}\text { Initial } \\
\text { capital }\end{array}$ & KRW 300 billion won & KRW 250 billion won \\
\hline Platform & Mobile & PC, Mobile (Smartphone, Tablet) \\
\hline $\begin{array}{l}\text { Major } \\
\text { service }\end{array}$ & $\begin{array}{l}\text { Simple remittance based on the Kakao } \\
\text { Talk address book, simple payment, } \\
\text { simple screening small loans, simple } \\
\text { overseas remittance (one-tenth of the } \\
\text { commission and telegraphic transfer fee } \\
\text { exemption service compared to the } \\
\text { market bank), small business loans, } \\
\text { Kakao Bank Friends check cards, fee } \\
\text { exemption, etc. }\end{array}$ & $\begin{array}{l}\text { Credit rating using big data, simple } \\
\text { payment, telephone address book- } \\
\text { based simple remittance, medium- } \\
\text { interest personal credit loans, small } \\
\text { credit loans for simple screening, } \\
\text { quick remittance, K-Bank check } \\
\text { cards, insurance business, } \\
\text { temporary fee exemption, etc. }\end{array}$ \\
\hline $\begin{array}{l}\text { Credit } \\
\text { loan } \\
\text { interest }\end{array}$ & $\begin{array}{c}\text { 3.92 4.06 (annual \%, Credit rating 3-4 } \\
\text { grade criteria) }\end{array}$ & $\begin{array}{c}\text { 4.2 5.49 (annual } \%, \text { Credit rating } 3- \\
4 \text { grade criteria) }\end{array}$ \\
\hline
\end{tabular}


Note: Reconstructed by referring to the official press release of the Financial Services Commission (2017) and articles on Chosun Biz's Choi \& Kim (2017)

According to Hwang (2019), one in five people of the nation made an account two years after the launch of the internet primary bank. Anyway, at the present of 2019, digital banks are already becoming a reality in Korea. However, what is important to financial services institutions will not be simply securing customers. A really important part will be to maintain a consistent customer base (Song, 2017). Internet primary bank are provided as services composed of customer centered, non-face-to-face services by combining big data, artificial intelligence, and blockchain with existing banks' systems to clearly understand their individual tendencies and personal behavior patterns (Robert \& Maria, 2014).

Like this the introduction of specialized banks was promoted by the demand of fintech in Korea, the demand for advancement of the banking industry, the emphasis on the importance of mobile channels, and the enhancement of consumer convenience. It was also expressed as 'Internet Only Bank' or 'Pure Play Internet Bank'. In recent years, Most of them are called 'Internet Primary Bank' or 'Internet Only Bank' is mainly expressed in the sense that the internet is the main channel (Sim, 2019). Therefore, in this study is used as a concept that is different from the internet banking that existing banks used to secure customer channels.

In Korea, since the launch of the internet primary bank, it has not been long since most researches on the launch or introduction of the bank (Yoon \& Joung, 2019A). Recently, an empirical study on the acceptance intention of internet primary banks has begun gradually. In this study, variables for confirming the reuse intention of the banks are examined. To this end, this study attempts to conduct empirical research on reuse intention based on consumer experiences by identifying meaningful variables through previous studies.

\subsection{Technology Acceptance Model}

Due to the emergence of the fintech industry, which means the convergence of finance and technology, social demands for changes in traditional financial services are increasing day by day (EY, 2017). In particular, with the development of the fintech industry led by global IT companies, the newly developed internet primary banks will bring changes to the existing financial market. In the rapidly restructuring of the financial industry, it is necessary to study the reuse intention of consumers who use the Korean internet primary banks in order to stabilize the newly emerged internet primary banks.

The theory of information technology acceptance can be verified using the Technology Acceptance Model derived from Theory of Reasoned Action. This technology acceptance model is supported by various empirical studies because of its concise and strong explanatory power to the acceptance of information 
technology (Davis, 1989). Davis (1989)'s technology acceptance model was developed based on the typical theory of rational behavior (Fishbein, \& Ajzen, 1975) and the theory of planned behavior (Ajzen, 1991), which is a representative theory for explaining human behavior. Davis (1989) proposed a model for computers that were innovative technologies in the mid-1980s to explain people's intent to accept, suggesting perceived usefulness and perceived convenience as determinants that could affect human attitudes and behavior. Subsequently, the model was expanded and modified and utilized in studies in various fields to identify factors affecting people's acceptance intentions or intentions for new technologies (Ha, 2017; Bang, 2018). Furthermore, the studies that have been predicted by modifying and applying the technology acceptance model with respect to reuse intentions for new technologies have proven that variables perceived usability and perceived convenience have a stronger effect on reuse intentions (Lee \& Ryu,, 2016).

Davis (1989), Venkatesh \& Davis (2000) defined an intention to reuse the service through the study of the extended technology acceptance model, and the degree of perception of how well they performed necessary tasks through the use of the new system. Jeong \& Park (2017) applied the extended technology acceptance model to conduct research on potential acceptance of internet primary bank consumers. In addition, Jeong (2017) revealed that perceived convenience has an effect on reuse intention through a study on the effect of fintech financial service characteristics on acceptance intention. It is said to be positively affected.

In addition, Shin (2018) confirmed that the perceived enjoyment of internet primary bank had a positive effect on sustainable use intention. Song (2017) said that consumers' beliefs and perceived pleasures in mobile internet service have a significant correlation with the intention to use new technologies continuously. Therefore, this study was conducted to investigate the effects of each variable on the intention of reuse of internet primary bank by adding variables such as perceived usefulness, perceived reliability, perceived pleasure and social influence to various preceding variables. The purpose of this study is to prove the correlation between the main antecedent variables of the intention of reuse of internet primary bank. For this purpose, a research model such as Figure1. was set up through the consideration of previous studies. 


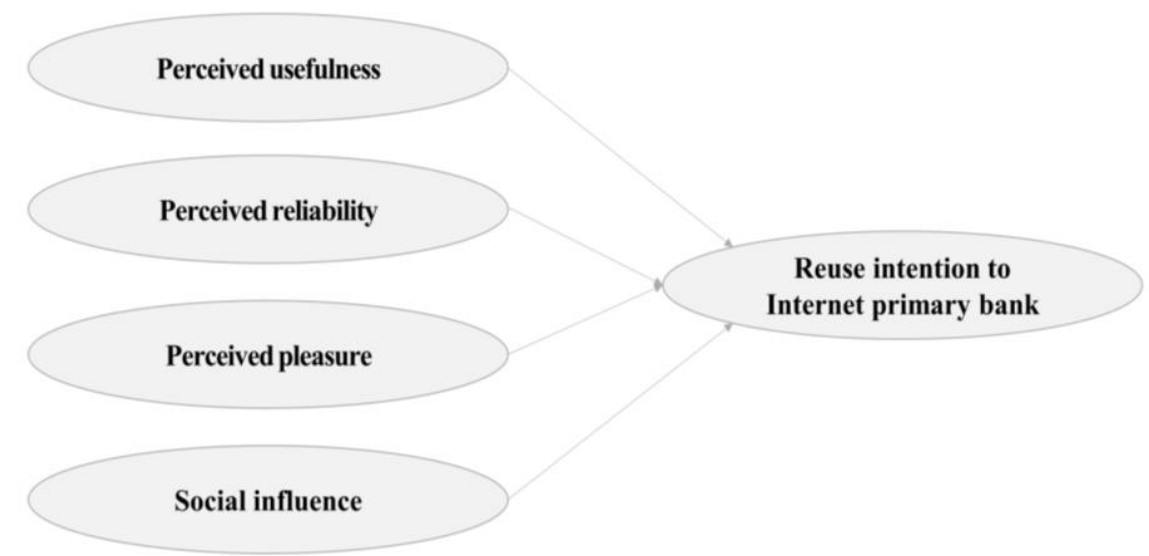

Fig 1: Research model

\section{Research and Result}

\subsection{Research and Samples}

This survey participants in order to proceed, a meeting of experts consisting of professors and researchers from the Consumer Studies was conducted three times to enhance the validity and reliability of this research. The first meeting was held on May 10, 2019, and the final survey was organized through the meeting on July 1 and July 15, 2019, the second meeting after the first survey of 50 adults in their 20s. And this research was conducted from 2 August to 10 August, 2019, and the samples of 234 adults in their 20s and 50s using Kakao Bank were conducted.

This study investigated the factors affecting the intention of reuse of internet primary bank for consumers using Kakao Bank, which shows a higher customer retention status than K-bank (Choi \& Kim, 2017). The reason why the sample was selected from the 20s to the 50s in Seoul, is because these consumers of the age are more proficient in using mobile and internet (Sim, 2019). According to the results of the 'Korea Media Panel Survey in 2018' conducted by Sim (2019), the characteristics of Internet bank users were the highest at $32.9 \%$ in their 20 s, and even $11.1 \%$ in their 50 s the use rate of double digits was shown, but it was very low in their 60s or older (Sim, 2019). So it is judged that it will be more suitable for the purpose of this study. A total of 234 adults, excluding 7 respondents who did not use Kakao Bank, were the subjects of the study. The SPSS and AMOS statistical packages were used to analyze the reliability and validity of the collected data, descriptive statistics analysis, and hypothesis verification.

\subsection{Results}


Exploratory factor analysis and reliability test were conducted to verify the validity and reliability of the questionnaire. The variables measured in this study were higher than .8, which confirmed that they had relatively satisfactory level of reliability. The questionnaires of each variable were composed as Table 2, and the descriptive statistical analysis of the variables was confirmed as Table 3. Among the collected 234 samples, 119 were male and 115 were female, and they were collected relatively similarly. They were sampled in their 50s $(8.6 \%)$ compared to their $20 \mathrm{~s}$ $(26.3 \%), 30$ s $(37.8 \%)$, and 40s $(27.3 \%)$, which confirmed that the use rate of Kakao Bank in their 50s was significantly lower.

The results of the study showed that the reuse intention was highly significant in the order of social influence, perceived usefulness, and perceived pleasure among the preceding variables. But, perceived reliability was not significant. Compared to previous prior studies, the variables that should be examined more carefully among the results of this study were social impact variables (Fig. 2). It was necessary to pay attention to the meaning of social influence variables that showed high significance in reuse intention. To this end, considering the characteristics of the users of Kakao Bank, which was the subject of this study, it was confirmed that the use of Kakao Bank through 'Kakao Talk Messenger', the mobile phone messenger used most by Koreans. In particular, Kakao Bank provides relatively easy and fast services such as instant remittance through Kakao Talk without knowing the account number of the other party. For this reason, the positive effect of social impact variables along with perceived usefulness. According to Yoon \& Joung (2019B), Koreans tend to value their image in a society that they consider to be important (Yoon \& Joung, 2019B; Yoon, 2019). We could guess that satisfaction has a positive effect on reuse intention. Through the results of this study, if marketing activities that can highlight these positive factors are continuously conducted and more special events are provided for existing customers, higher reuse intentions.

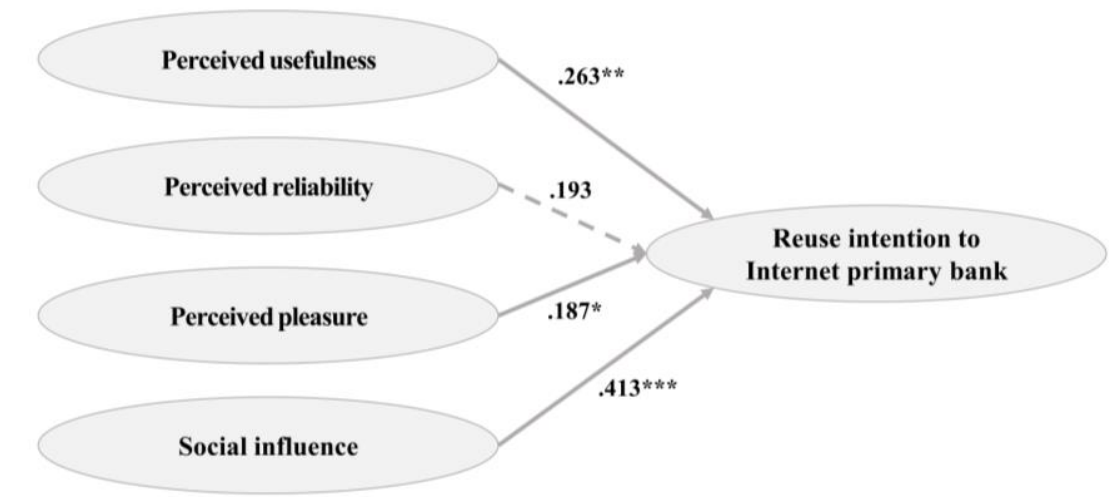

Notes: $* * * \mathrm{p}<.001 ; * * \mathrm{p}<.01$

Fig. 2: SEM results 
Table 2: Questions and sources of variables

\begin{tabular}{|c|c|c|}
\hline Variable & Measurement Questions & Source \\
\hline $\begin{array}{l}\text { Perceived } \\
\text { usefulness }\end{array}$ & $\begin{array}{l}\text { 1. The use of a Kakao bank may save time for using } \\
\text { banking services. } \\
\text { 2. The Kakao Bank application is intuitively } \\
\text { designed to be used. } \\
\text { 3. Using a Kakao bank, financial fees, etc. may be } \\
\text { saved; } \\
\text { 4. It is easy to use in connection with KakaoTalk } \\
\text { accounts. } \\
\text { 5. Kakao banks may be used regardless of time. }\end{array}$ & $\begin{array}{l}\text { Yoon \& Joung } \\
\quad(2019 B), \\
\text { Davis(1989) }\end{array}$ \\
\hline $\begin{array}{l}\text { Perceived } \\
\text { reliability }\end{array}$ & $\begin{array}{l}\text { 1. Kakao Bank will be offering higher monetary } \\
\text { benefits than commercial banks. } \\
\text { 2. The Kakao Bank will lower its financial losses. } \\
\text { 3. Personal information of Kakao Bank will be } \\
\text { managed safely. } \\
\text { 4. Kakao Bank is a reliable company. }\end{array}$ & Davis(1989) \\
\hline $\begin{array}{l}\text { Perceived } \\
\text { pleasure }\end{array}$ & $\begin{array}{l}\text { 1. The use of Kakao Bank is fun } \\
\text { 2. It's interesting to use Kakao Bank. 3. It's fun to use } \\
\text { Kakao Bank. }\end{array}$ & $\begin{array}{c}\operatorname{Shin}(2018), \\
\text { Davis(1989) }\end{array}$ \\
\hline $\begin{array}{c}\text { Social } \\
\text { influence }\end{array}$ & $\begin{array}{l}\text { 1. Using Kakao Bank, others will see me as an } \\
\text { innovative person. } \\
\text { 2. It seems that using Kakao Bank makes you feel } \\
\text { like an early adopter than others. } \\
\text { 3. Using Kakao Bank will strengthen my image more } \\
\text { positively from the people around me. }\end{array}$ & Shin(2018), \\
\hline $\begin{array}{l}\text { Intention to } \\
\text { reuse }\end{array}$ & $\begin{array}{l}\text { 1. I will re-use Kakao Bank. } \\
\text { 2. I want to continue using Kakao Bank. } \\
\text { 3. I will use Kakao Bank again. }\end{array}$ & $\begin{array}{l}\text { Yoon (2019), } \\
\text { Davis(1989) }\end{array}$ \\
\hline
\end{tabular}

Table 3. Descriptive statistics of the variables

\begin{tabular}{|c|c|c|c|c|}
\hline Variables & Mean & Std. Dev. & Min & Max \\
\hline Perceived usefulness & 3.712 & 0.782 & 1 & 5 \\
\hline Perceived reliability & 4.420 & 0.661 & 1 & 5 \\
\hline Perceived pleasure & 3.750 & 0.897 & 2 & 5 \\
\hline Social influence & 3.413 & 0.862 & 1 & 5 \\
\hline Intention to reuse & 3.912 & 0.789 & 1 & 5 \\
\hline
\end{tabular}




\section{Conclusion}

The development of IT and rapid spread of the financial service spread widely, most banking services are moving toward strengthening online. In South Korea, Internet primary bank has begun to provide financial services combined with IT convergence technology. The number of Internet primary banking subscribers increased rapidly in the beginning due to customer interest and expectation, but this phenomenon was not continuous and subscriber growth has stagnated. The results of the study showed that the reuse intention was highly significant in the order of social influence, perceived usefulness, and perceived pleasure among the preceding variables. But, perceived reliability was not significant. Therefore, it is thought that in order to increase the reuse rate of Internet primary banking, consumers should pay more attention to the factors carry out marketing accordingly.

This study has a limitation in that there was on age of samples in their $20 \mathrm{~s}$ to $50 \mathrm{~s}$. On the social side of modern society, where convenience through emphasis on Digital Bank Based on Information and Communication Technology (ICT) is being emphasized, there is a growing concern about marginalized groups (Jung, 2017), such as older people who cannot adapt to the digital age. Therefore, in the next study, if the study that considers the digital marginalized class by expanding the age range is progressed, it will be developed into a more meaningful study. In addition, we hope that empirical research can be conducted through the introduction of more diverse and new variables. In spite of some of these limitations, this study was conducted in Korea in that it conducted research on Internet primary bank in a relatively early stage.

It is also expected that more consumers will be able to reuse and even bring in new consumers if the focus is on providing high levels of usability that consumers can use directly for service use factors such as the Internet or smartphones. We hope this research will help in marketing Internet primary banking services, and we hope that further research will be conducted using more meaningful prior parameters.

\section{References}

Ajzen, I. (1991). The theory of planned behavior. Organizational behavior and human decision, 50, 179-211.

Bang. K. H. (2018). A study on the acceptance intention of individual users of internet banks : Focusing on technology acceptance model. Master Degree, Konkuk University, South Korea.

Cha, J. S. (2018). Digital banking, changing society. Newsway. http://www.newsway.co.kr/news/view?ud=2017122811490869001 
Choi, K. \& Kim, M. (2017). Kebang Storm defeated by the Kabang, ChosunBiz's.

Chris, S. (2015). Digital dank digital bank: Strategies to launch or become a digital Bank. Marshall Cavendish International (Asia) Pte L., 1-145.

Davis. F. D. (1989). Perceived usefulness, perceived ease of use, and user acceptance of information technology, MIS Quarterly, 13 (3), 319-340.

EY. (2017). EY Fintech Adoption Index 2017: The Rapid Emergence of Fintech. 144. https://www.ey.com/Publication/vwLUAssets/ey-fintech-adoption-index2017/\$FILE/ey-fintech-adoption-index-2017.pdf

Fishbein, M. \& Ajzen, I. (1975). Belief, Attitude, Intention, and Behavior: An Introduction to Theory and Research, Reading. MA: Addison-Wesley.

Financial Services Commission. (2017). Recent Trends in Internet-only Banks and Movements to Respond to Financial Sector. press release, 4

Ha, J. S. (2017). A Study on the Determinants of Acceptance Intention to Accept Simplified Payment Service. PhD. Dissertation, Keimyung University, South Korea.

Hwang, J. (2019). 'Where Internet players have increased the number of players' Insufficient innovative business model, fear of bleeding competition. Joongang sisa magazine, https://jmagazine.joins.com/economist/view/325542

Jeffry, P. (2014). 3 Tips to deliver different, Credit unicom times.

Jeong, E. J. \& Park, H. S. (2017). An empirical study on the user acceptance of internet primary bank based on UTAUT2, The e-business studies. 18(3), 75-95.

Jeong. T. K. (2017). A Study on the Influence of Characteristics of Fin-Tech System on Consumer Acceptance: Focused on Mobile Banking, PhD. Dissertation, Busan University, South Korea.

Jung, M. S. 2017. Digital Today, Internet primary bank, which is the exclusive property of 2040 generations, and the elderly are concerned about the financial underprivileged.

http://www.digitaltoday.co.kr/news/articleView.html?idxno=110744

Kang, D. G. 2017. A legal study on launching the internet primary bank, PhD. Dissertation, Kyunghee University, South Korea.

Kim, D.W. and Kim, S. C. 2017. Factors to influence switching intention to internet-only bank from Legacy Bank: Focused on financial consumers' asset management, The Korean Association for Information Society, 18(1), 105-134.

Korea Economy, (08.23. 2018.). http://www.oecd.org/economy/korea-economicsnapshot/ 
Lee, S. \& Ryu, M. (2014). The effects of TV home shopping`s consumption value on satisfaction and repurchase intentions: Focused on expanded technology acceptance model (ETAM). Consumer Studies Research, 25(6), 133-156.

McAuley. (2014). An economic industry composed of companies that use technology to make financial systems more efficient. Wharton Fintec club.

Robert Gach \& Maria Gotach, The rise of fintech: New York's opportunity for tech leadership, Accenture.

Seo, B. H. (2015). Korean Internet Bank Introduction Plan. Korean Economic and Financial Review. https://www.fsc.go.kr/downManager?bbsid=BBS0030\&no=96018

$1-70$.

Shin, K. S. (2018). The Effect of Perceived Value and Perceived Risk on Satisfaction and Continuation Intention of Internet Banks, Master Degree, Korea University, South Korea.

Sim, D. N. (2019). User Characteristics of Internet Banks, Korea Information Society Development Institute. KISDI STAT REPORT. 19(6). https://m.biz.chosun.com/svc/article.html?contid=2017112703238

Song, S.(2017). The study of business model on fintech Internet only bank, The $e$ business studies, 17(3),

273-299.

http://m.newsway.co.kr/news/view?ud=2017122811490869001

The Korea Financial Supervisory Service. (2016), http://www.fss.or.kr/fss/kr/main.html

Venkatesh, V. \& Davis. F. D. (2000). A theoretical extension of the technology acceptance model: Four longitudinal field studies. Management Science. 46(2). 186-204.

Yoon, J. (2019). A study on an eco-friendly product purchase process using expanded theory of planned behavior. PhD. Dissertation, Ewha Womans University, South Korea.

Yoon, J.\& Joung, S. (2019. A). A study on reuse intention of digital bank in south Korea. International Journal of Business Policy and Strategy Management, 6(1).

Yoon, J. \& Joung, S. (2019 B). Examining purchase intention of eco-friendly products: A comparative study. Journal of System and Management Sciences, 9(3),123-135.

$\mathrm{Yu}, \mathrm{H}$ (2019). Kakao Bank has surpassed 10 million members in two years. Kyunghyang Biz Economy. http://biz.khan.co.kr/khan_art_view.html?artid=201907121138001\&code=920301 